\title{
Imported wasp helps control southern green stink bug
}

\author{
Michael P. Hoffmann a Nita A. Davidson a Lloyd T. Wilson \\ Lester E. Ehler 口 Walker A. Jones a Frank G. Zalom
}

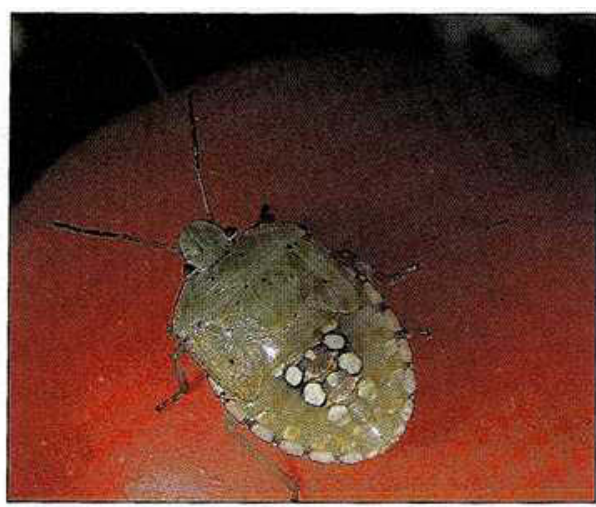

Southern green stink bug in the late instar nymph stage.

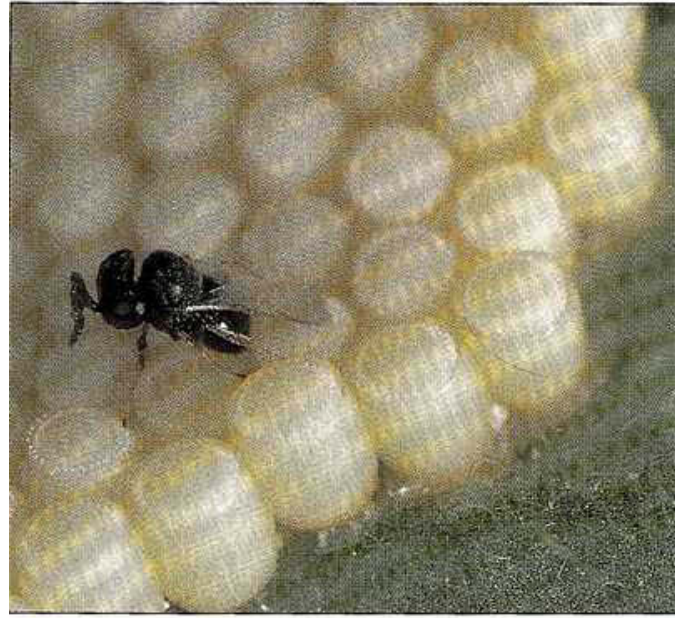

Imported wasp (Trissolcus basalis) which parasitizes eggs of the southern green stink bug.



Southern green stink bug.

\section{Scientists have introduced a Euro- pean wasp which parasitizes eggs of the destructive southern green stink bug, a pest recently discov- ered in California. The beneficial wasp appears to be established and effective against not only the southern green stink bug but some species of native stink bugs as well.}

The southern green stink bug, Nezara viridula, is a destructive agricultural pest worldwide, feeding on more than 30 different crops: vegetables, grains, fruits and nuts, and a variety of weeds. It is the primary pest of soybeans in many parts of the world. The southern green stink bug (SGSB) is known to feed on and damage tomatoes, a major crop in California. Stink bug feeding damage to fresh market tomatoes can reduce crop quality and result in economic losses to producers. The SGSB has also been associated with fungal and bacterial diseases of crop plants. This includes the yeast Nematospora, which causes tomato fruit rot, a concern to producers of processing tomatoes.

SGSB was first discovered in California in 1986, located in a field of processing tomatoes between Davis and Woodland in Yolo County (see California Agriculture, May-June 1987). Until this discovery, the distribution of SGSB in the United States was limited to the Southeast, extending only to eastern Texas. Today the SGSB is found in the California counties of Contra Costa, Sacramento, San Joaquin, San Diego, Solano and Yolo. It is thought to be permanently established and may occur elsewhere, but this has not been documented.

Soon after discovery of SGSB in California it was apparent that this new pest could seriously threaten a variety of crops. At the discovery site we recorded as many as 25 bugs per yard of tomato bed, and the crop was heavily damaged. The year following its discovery, urban gardens in Davis were heavily damaged. At one heavily infested site on the University of California, Davis campus, up to $100 \%$ of the tomatoes and other vegetables were ruined by SGSB feeding. Within a few months following its discovery, we recorded SGSB feeding on many other host plants, including sweet corn, sunflower, beans, broccoli, squash, okra, peppers, pumpkin, eggplant, citrus, lambsquarters, morning glory, nightshade, cheeseweed, Russian thistle, and pigweed.

Prior to the discovery of SGSB in California, an extensive survey of indigenous stink bug parasites was underway. This survey indicated that eggs of indigenous stink bugs were parasitized by several species of small wasp (Scelionidae and Encyrtidae), and that a few species of fly parasites (Tachinidae) were attacking nymphs and adults. Once SGSB was discovered in California, additional surveys were conducted. Based on examination of over 200 SGSB field-layed or exposed egg masses, it was apparent that no effective natural enemies were present and that a classical biological control program should be undertaken to bring appropriate natural enemies into California.

In the past, SGSB was accidentally introduced into Australia (1916), New Zealand (1944), and Hawaii (1961) and subsequently brought under biological control, either by introduction of the wasp Trissolcus basalis, an egg parasite, alone, or in combination with a parasitic fly. Given this historical evidence, T. basalis was the logical choice for introduction into California.

\section{Methods \& Materials}

In cooperation with the U.S. Department of Agriculture, Agricultural Research Service, European Parasite Laboratory in France, $T$. basalis was collected from the Mediterranean areas of France, Italy, and Spain. We decided to collect it from this region because the climate is similar to that of the Sacramento Valley. Egg masses of SGSB that had been parasitized by $T$. basalis were shipped to the Department of Entomology at UC Davis where they were held in quarantine for one generation. Following quarantine, separate colonies of French, Italian, and Spanish T. basalis were established. Colonies were maintained and propagated by providing each with a supply of fresh, unparasitized egg masses of SGSB and indigenous stink bug species.

Egg masses for the parasite colonies and laboratory and field studies were obtained from colonies of southern green, consperse (Euschistus conspersus), redshouldered (Thyanta pallidovirens), "Say" (Chlorochroa uhleri), and conchuela (C. ligata) stink bugs. These species were provided a diet of green beans and sunflower seeds. Another species, harlequin bug (Murgantia histrionica) was reared on a diet of cabbage. 
The bugs deposited most egg masses onto brown paper towels in the rearing containers. About every 2 days, masses were collected by cutting strips ( $1 / 2$ inch $\times 3$ inches) containing eggs from the paper towels. The strips of paper towel aided in manipulating egg masses in the parasite colonies and in the field.

Field releases of T. basalis began in September of 1987 at Davis. These and subsequent releases were conducted using three techniques: 1) direct release of adult parasites, 2) release of adult parasites into wiremesh or cloth cages containing vegetation and fresh unparasitized egg masses of stink bugs and/or colonies of bugs, and 3) placement of stink bug egg masses (parasitized by $T$. basalis) in the field. The last technique was the easiest and most commonly used, especially when parasites were mailed to other locations where cooperators could easily take egg masses and place them in the field before adults of T. basalis emerged. Subsamples of egg masses placed in the field were subsequently collected to determine the percentage of parasites that emerged.

SGSB egg masses can also be deep frozen $\left(-94^{\circ} \mathrm{F}\right)$ to kill the developing stink bugs. Once thawed, these eggs are still suitable hosts for parasites. This freezing process allowed us to ship parasitized egg masses to areas not yet infested by SGSB, with no risk of furthering the spread of the pest.

T. basalis were released at selected sites in Contra Costa, Fresno, Kern, San Joaquin, Stanislaus, Sacramento, San Diego, Solano, and Yolo Counties. In 1987, several hundred T. basalis were released. An estimated 180,000 T. basalis adults were released during 1988 and 1989. Release sites typically were urban gardens and organic or low pesticide-use farms or crops.

The vegetation and potential hosts at the release sites varied considerably. Most often, however, the release sites were weedy and infested with SGSB or a native stink bug species. These sites had the greatest potential to function as field insectaries and stable reservoirs from which T. basalis could disperse to surrounding habitats.

Releases were not made in 1989 at a number of 1988 release sites so that we could determine if $T$. basalis survived the winter. However, they were released in 1989 in Fresno, Kern and Stanislaus Counties in anticipation of the SGSB ultimately dispersing into these areas.

Followup studies were conducted on a regular basis to determine if $T$. basalis was parasitizing stink bug eggs. We either collected naturally occurring stink bug egg masses or used "sentinel" egg masses. The first technique was very time-consuming and generally did not yield many masses.
Sentinel egg masses were fresh and unparasitized masses that were cut from the paper towelling along with a strip of paper (described above). These strips of paper were generally clipped to vegetation in the field and after about 3 days they were retrieved and returned to the laboratory where they were placed in small gelatin capsules for observation. Followup studies started as early as March and were repeated two to three times a month at most release sites until late summer or fall.

The following information was recorded for each egg mass collected from the field: number of nymphs and parasites by species that emerged; number of dead, unhatched, and cannibalized eggs, and number of eggs consumed by predators. Not only did this quantify parasitism of SGSB and indigenous bugs by $T$ basalis, it also provided data on parasitism of SGSB by indigenous stink bug parasites, and provided an extensive survey and measure of the importance of indigenous parasites as mortality agents of indigenous stink bugs.

Percentage parasitism per egg mass was calculated by dividing the number of parasitized eggs by the total number of eggs in the mass. The rate of parasitism was also calculated for all eggs by dividing the total number of eggs parasitized by the total number of eggs placed in the field. Eggs that failed to hatch for undetermined reasons were included in the calculations (denominator), but eggs that were cannibalized or consumed by predators were excluded.

These rates of parasitism are "best estimates" of the actual rates occurring in field populations. The probability that a sentinel egg mass would be discovered by parasites may have been influenced by its proximity to stink bug and associated parasite populations. Putting sentinel egg masses at a known stink bug infestation, but out of synchrony with the life cycle of the parasite(s), could also affect rates of parasitism. In addition, how and if the paper strip influenced the behavior of the parasites and rates of discovery or parasitism is not known.

\section{Results and discussion}

The survey of parasites of indigenous stink bugs conducted from early 1987 through 1989 revealed the presence of seven indigenous species of egg parasites (Encyrtidae or Scelionidae) and three indigenous species of parasitic flies (Tachinidae) (table 1). Trissolcus basalis was not collected until following its release in September 1987. Although hundreds of nymphal and adult stink bugs of several species were collected from a variety of habitats during these studies, relatively few tachinids emerged from stink bugs. None were recorded successfully parasitizing SGSB, although tachinid eggs were occasionally present on adults. However, the complex of indigenous egg parasites did contribute to the mortality of stink bugs. Egg predation and cannibalism were minor mortality factors, whereas the percentage of eggs not hatching for unknown causes was relatively high $(>20 \%)$.

Five species of indigenous parasites were recorded parasitizing eggs of the SGSB (table 1). The encyrtids, which parasitize several hosts, attacked eggs of the SGSB as well as every other stink bug species for which we collected data. However, the rates of parasitism by the encyrtids were relatively low (table 2). Parasitism by the indigenous scelionids was not common either, and their overall impact on

\begin{tabular}{|c|c|c|c|c|c|c|}
\hline \multirow[b]{2}{*}{ Parasite } & \multicolumn{6}{|c|}{ Stink bug } \\
\hline & N. viridula & $\begin{array}{l}\text { E. con - } \\
\text { spersus }\end{array}$ & $\begin{array}{l}\text { T. palli- } \\
\text { dovirens }\end{array}$ & C. uhleri & C. ligata & $\begin{array}{l}\text { M. histri- } \\
\text { onica }\end{array}$ \\
\hline \multicolumn{7}{|l|}{$\begin{array}{l}\text { Hymenoptera: } \\
\text { Encyrtidae }\end{array}$} \\
\hline $\begin{array}{l}\text { Ooencyrtus californicus } \\
\text { Ooencyrtus johnsoni }\end{array}$ & $\begin{array}{l}+ \\
+\end{array}$ & $\begin{array}{l}+ \\
+\end{array}$ & + & $\begin{array}{l}+ \\
+\end{array}$ & $\begin{array}{l}+ \\
+\end{array}$ & $\begin{array}{l}+ \\
+\end{array}$ \\
\hline \multicolumn{7}{|l|}{ Scelionidae } \\
\hline $\begin{array}{l}\text { Trissolcus basalis }{ }^{\dagger} \\
\text { Trissolcus utahensis } \\
\text { Trissolcus euschisti } \\
\text { Gryon obesum } \\
\text { Telenomus podisi } \\
\text { Psix tunetanus }\end{array}$ & $\begin{array}{l}+ \\
+ \\
+ \\
+ \\
+\end{array}$ & $\begin{array}{l}+ \\
+ \\
+ \\
+ \\
+ \\
+\end{array}$ & $\begin{array}{l}+ \\
+ \\
+ \\
+ \\
+\end{array}$ & $\begin{array}{l}- \\
+ \\
+ \\
+ \\
+ \\
+\end{array}$ & $\begin{array}{l}- \\
+ \\
+ \\
+ \\
- \\
-\end{array}$ & $\begin{array}{l}+ \\
+ \\
+ \\
+\end{array}$ \\
\hline \multicolumn{7}{|l|}{$\begin{array}{l}\text { Diptera: } \\
\text { Tachinidae }\end{array}$} \\
\hline $\begin{array}{l}\text { Gymnoclytia occidentalis } \\
\text { Gymnosoma filiola } \\
\text { Cylindromyia fumipennis }\end{array}$ & - & $\begin{array}{l}+ \\
+ \\
+\end{array}$ & $\begin{array}{l}+ \\
+ \\
+\end{array}$ & + & : & $\therefore$ \\
\hline
\end{tabular}




\begin{tabular}{|c|c|c|c|c|c|c|c|}
\hline \multirow[b]{3}{*}{$\begin{array}{l}\text { Location } \\
\text { and date }\end{array}$} & \multirow[b]{3}{*}{$\begin{array}{l}\text { No. egg } \\
\text { masses }^{\star}\end{array}$} & \multicolumn{6}{|c|}{ Percent parasitization } \\
\hline & & \multicolumn{2}{|c|}{ T. basalis } & \multicolumn{2}{|c|}{ O. californicus } & \multicolumn{2}{|c|}{ O. johnsoni } \\
\hline & & $\begin{array}{c}\text { Exploited } \\
\text { masses }(n) \dagger\end{array}$ & $\begin{array}{l}\text { All } \\
\text { eggsf }\end{array}$ & $\begin{array}{c}\text { Exploited } \\
\text { masses }(n) \dagger\end{array}$ & $\begin{array}{c}\text { All } \\
\text { eggs } \neq\end{array}$ & $\begin{array}{c}\text { Exploited } \\
\text { masses }(n) \dagger\end{array}$ & $\begin{array}{c}\text { All } \\
\text { eggs }\end{array}$ \\
\hline \multicolumn{8}{|c|}{$\begin{array}{l}\text { Yolo and Solano } \\
\text { Counties: }\end{array}$} \\
\hline \multicolumn{8}{|l|}{1987} \\
\hline June-July & 25 & -- & & $51 \quad(2)$ & 3 & $23 \quad(3)$ & 2 \\
\hline Aug.-Sept. & 151 & $50 \quad(8)$ & 2 & $11(12)$ & 1 & -- & \\
\hline Oct. Nov. & 69 & $21 \quad(4)$ & 1 & $6(3)$ & $<1$ & -- & \\
\hline \multicolumn{8}{|l|}{1988} \\
\hline Apr.-May & 68 & $56 \quad(6)$ & 5 & 1 (1) & $<1$ & $-(1)$ & $<1$ \\
\hline June-July & 56 & 75 (9) & 13 & 14 (2) & $<1$ & $54 \quad$ (2) & $<1$ \\
\hline Aug.-Sept. & 100 & $73(15)$ & 12 & $11(13)$ & 2 & $9(1)$ & $<1$ \\
\hline Oct.-Nov. & 38 & 75 (12) & 24 & 17 (1) & $<1$ & -- & \\
\hline \multicolumn{8}{|l|}{1989} \\
\hline March & 6 & -- & - & -- & - & & \\
\hline Apr.-May & 43 & 75 (1) & 2 & -- & - & - & \\
\hline June-July & 108 & $73(16)$ & 13 & $4(1)$ & $<1$ & 5 (1) & $<1$ \\
\hline Aug. Sept. & 75 & 75 (21) & 21 & $12(3)$ & $<1$ & 8 (4) & $<1$ \\
\hline Oct.Nov. & 24 & $75(7)$ & 27 & -- & - & - & \\
\hline \multicolumn{8}{|c|}{ Contra Costa County: } \\
\hline \multicolumn{8}{|l|}{1988} \\
\hline Oct.-Nov. & 18 & $93(16)$ & 83 & $22(1)$ & 1 & - & - \\
\hline \multicolumn{8}{|l|}{1989} \\
\hline June-July & 16 & $96 \quad(4)$ & 23 & - & - & - & \\
\hline Aug.-Sept. & 30 & $79(19)$ & 49 & - & - & 3 (1) & $<1$ \\
\hline
\end{tabular}

SGSB was minimal. The general lack of effective indigenous parasites of SGSB eggs or adults provided convincing support for the decision to import and release T. basalis in California.

Surveys conducted following the release of $T$. basalis showed that this parasite attacked not only eggs of SGSB, but also those of consperse and redshouldered stink bugs (table 1). When T. basalis discovered an egg mass of the redshouldered or consperse stink bugs, it generally parasitized over $60 \%$ and $75 \%$ of the eggs, respectively. The availability of alternate hosts suggests that T. basalis can survive in the absence of SGSB. This may increase the likelihood of T. basalis becoming an effective biological control agent for SGSB. It also means that $T$. basalis might be helpful in controlling indigenous stink bugs.

Shortly following its release in September 1987, T. basalis was recovered from sentinel egg masses of the SGSB (table 2). Of the 138 sentinel SGSB egg masses located and parasitized by T. basalis during 1987,1988 , and 1989, the rate of parasitism per mass was frequently greater than $70 \%$ (table 2). The rate of parasitism of all eggs was much lower, but several fold greater than that recorded for indigenous parasites.

In addition to sentinel eggs, egg masses collected from naturally occurring populations of SGSB showed similar results. For example, during September and October
1988,41 of 46 SGSB egg masses collected from a field of cowpeas in Contra Costa County were located and parasitized by $T$. basalis. On average, $87.2 \%$ of the eggs per mass were parasitized, and parasitism of all eggs was $79.9 \%$. This provided strong evidence that $T$. basalis could readily locate and parasitize SGSB eggs in field popula tions.

The ability of $T$. basalis to overwinter, a critical question relevant to the successful establishment of an introduced parasite, was demonstrated at selected sites in Contra Costa, Sacramento, Solano, and Yolo Counties. For example, the parasitism recorded in Contra Costa County in 1989 (table 2), resulted from T. basalis that had overwintered from 1988.

\section{Summary}

Our results indicate that $T$. basalis appears to be established in Northern California. Because it is capable of parasitizing a relatively large percentage of the stink bug eggs that it locates, this parasite has the potential to be an effective biological control agent for SGSB and some native stink bug species. Its long-term ecological impact on both SGSB and native stink bugs will require additional research.

M. P. Hoffmann was Staff Research Associate, Department of Entomology, UC Davis, and is now Assistant Professor, Department of Ento- mology, Cornell University; N. A. Davidson is Post-Doctoral Researcher, Department of Entomology, UC Davis; L. T. Wilson was Professor and Entomologist at UC Davis, and is currently Professor, Department of Entomology, Texas A\&M University; L. E. Ehler is Professor, Department of Entomology, UC Davis; W. A. Jones was previously Research Entomologist with the USDA European Parasite Laboratory, France, and is now with USDA$A R S$ Bee Biology and Biological Control of Insects Laboratory, Tucson, AZ, and F. G. Zalom is Extension Entomologist and Director, Statewide IPM Project, UC Davis.

The authors acknowledge the valuable assistance of UC Cooperative Extension Farm Advisors Liese Greensfelder, formerly in Contra Costa Co.; Rich Coviello, Fresno Co.; Walt Bentley, Kern Co.; Wynette Sills, formerly in Sacramento Co., Bob Mullen, San Joaquin Co., Richard Smith and Jesus Valencia, formerly and currently in Stanislaus Co., respectively. The assistance of Richard Rice at the UC Kearney Agricultural Center, personnel with the San Diego and Contra Costa Agricultural Commissioner's Office, and several growers is also appreciated. The assistance and cooperation of the USDA-ARS EUropean Parasite Laboratory is gratefully acknowledged. This project was supported in part by the UC IPM Implementation Group and the California Fresh Market Tomato Advisory Board. 